\title{
Role of Genetic and Environmental Factors in the Increased Blood Pressures of Bolivian Blacks
}

\author{
A. ROBERTO FRISANCHO, ${ }^{1 *} \mathrm{~S}$. FARROW, ${ }^{2}$ ISABEL FRIEDENZOHN ${ }^{3}$ \\ TIFFANY JOHNSON, ${ }^{3}$ BETH KAPP,${ }^{3}$ CHRISTINA MIRANDA, ${ }^{3}$ \\ MARIA PEREZ, ${ }^{3}$ ISHA RAUCHLE, ${ }^{3}$ NICHOLAS SANCHEZ, ${ }^{3}$ \\ GLORIA WHEATCROFT ${ }^{3}$ LITA WOODILL, ${ }^{4}$ IRMA AYLLON,${ }^{5}$ \\ DIVA BELLIDO ${ }^{5}$ ARMANDO RODRIGUEZ, ${ }^{5}$ JORGE MACHICAO,${ }^{5}$ \\ MERCEDES VILLENA, ${ }^{5}$ AND ENRIQUE VARGAS ${ }^{5}$ \\ ${ }^{1}$ Center for Human Growth and Development and Department of \\ Anthropology, University of Michigan, Ann Arbor, Michigan \\ ${ }^{2}$ Wayne State University, Detroit, Michigan \\ ${ }^{3}$ Undergraduate students participating in the Minority International \\ Research Training (MIRT) program of the University of Michigan \\ Minority Fogarty Training Program \\ ${ }^{4}$ University of Guelph, Guelph, Canada \\ ${ }^{5}$ Instituto Boliviano de Biologia de Altura (IBBA), La Paz, Bolivia
}

\begin{abstract}
The tendency toward hypertension or higher blood pressure is more common in blacks than whites. The factors that account for these differences are attributed to both environmental and genetic factors. To clarify this issue, an anthropological study of black and nonblack populations in the lowland village of Chicaloma, northeastern Bolivia at a midaltitude of $1,800 \mathrm{~m}$ was conducted. The study included 159 subjects, of which 79 were black and 80 were nonblack, $17-78$ years. The study suggests the following: (1) the socioeconomic status of blacks as measured by an ownership index is greater than that of nonblacks, (2) blacks had higher average systolic and diastolic blood pressures than nonblacks and showed an age-associated increase in blood pressures, (3) the prevalence of hypertension was higher for blacks $(7-6 \%)$ than nonblacks $(1.3 \%)$, but three times lower than among blacks in the United States, (4) skin reflectance is inversely related to blood pressures so that contrary to what has been suggested the darker the skin color, the higher the blood pressures even at comparable levels of affluence. These findings together suggest that genetic factors predispose black individuals to increased blood pressures, but the expression of clinical hypertension is influenced by adverse unaccounted environmental factors. Am. J. Hum. Biol. 11:489-498, 1999. ๑ 1999 Wiley-Liss, Inc.
\end{abstract}

\section{INTRODUCTION}

In general, African-American blacks have higher blood pressure than nonblacks. At the individual level, variability in blood pressure is determined by the interplay of blood volume and arteriolar constriction so that high blood volume associated with vasoconstriction results in high blood pressure. Since sodium produces both intravascular volume expansion and vasoconstriction, variability in either intake or retention of salt would influence blood pressure. The factors that account for these differences are attributed to both environmental and genetic factors.

Experimental and clinical studies have shown that blacks in the United States have an enhanced sodium retention and a greater increase in blood pressure in response to $\mathrm{Na}+$ intake than whites (Luft, 1977; Aviv et al., 1990; Hall, 1990). Similarly, epidemiological studies indicate that blacks ingest similar amounts of dietary salt than non-

Contract grant sponsor: NIH-Fogarty Minority International Research Training grant; Contract grant number: 1T3700035 (to the Center for Human Growth).

*Correspondence to: Dr. A. Roberto Frisancho, Center for Human Growth and Development, $300 \mathrm{~N}$. Ingalls, University of Michigan, Ann Arbor, MI 48109-0406. E-mail: arfrisan@ umich.edu

Received 27 January 1998; Revision received 22 May 1998; Accepted 26 May 1998 
blacks (Frisancho and Leonard, 1984). It has been postulated that the genetic tendency to maintain higher blood pressure in blacks is the result of high retention of salt that might have evolved as an adaptation to the hot tropical climate of Africa and/or as result of selection during the transport of slaves from Africa to America (Gleibermann, 1973, 1975; Grim et al., 1980).

In contrast, the environmental hypothesis postulates that the environmental stresses of poverty and low socioeconomic status to which blacks are generally exposed are the main factors involved in high blood pressure. This hypothesis is based on evidence that the prevalence of hypertension in African-Americans is higher than that in the Caribbean and Brazilian black populations (Johnson and Remington, 1961; Johnson et al., 1975; Ribeiro et al., 1981; CoroniHuntley et al., 1989; Dressler, 1987, 1991; James et al., 1991; Saunders, 1991). As inferred from current reviews (Dressler, 1987, 1991; James et al., 1991; Moorman et al., 1991; Calhoun, 1992; Williams, 1992), the increasing incidence of hypertension in developing nations is related to socioeconomic and behavioral traits associated with urban environments. It has been hypothesized that high blood pressure among U.S. blacks is related to socio-cultural stress resulting from the struggle of individuals of dark skin color to establish and maintain a middleclass life style (Dressier, 1990, 1991; Moorman et al., 1991; Calhoun, 1992; Williams, 1992).

In summary, it is not clear the extent to which the observed higher tendency toward hypertension or higher blood pressure in African-American blacks is related to sociocultural stress in populations where skin color is not an important criterion of social class as it is the United States. Similarly, if the increased frequency of hypertension is related to genetic factors, it is not known whether it is expressed under conditions where blacks are of equal socioeconomic condition as nonblacks. For this reason, an anthropological study of black and nonblack populations living in the lowland village of Chicaloma, northeastern Bolivia at a midaltitude of 1,800 m, was conducted.

\section{MATERIALS AND METHODS Sample}

The analysis is based upon a sample of 159 subjects ranging in age from 17 to 78 years. The subjects were classified as either black or nonblack using: (1) individual selfidentification, each participant being asked whether he/she considers him/herself as black or mestizo, (2) individual surname, last names being traced as of Aymara, Quechua, or Spanish ancestry, and (3) anthroposcopic observation by the principal investigator (ARF). Through these procedures, 92 subjects were classified as black and 67 were classified as nonblack. The latter included individuals of predominantly Aymara or Aymara mixed with Spanish ancestry. The sample represented $50 \%$ of the total adult populations of the village of Chicaloma in June 1995. The protocol for the study was approved by a Human Subjects Review Committee at the University of Michigan and the Bolivian Institute of Biology and Altitude (IBBA).

\section{Study population}

In geographic terms, the town of Chicaloma where the study was conducted, at a midaltitude of $1,800 \mathrm{~m}$, belongs to a subtropical region. Because of the semitropical and Andean location, there are no clear differences between the full seasons aside from the two defined seasons of summer (December through April) and winter (May through November). Summer is characterized by high temperatures and humidity with an average temperature of $95^{\circ} \mathrm{F}$ and $80 \%$ humidity, whereas winter is characterized by mild temperatures averaging $75^{\circ} \mathrm{F}$ and $50 \%$ humidity.

Until the 1960s, the economic base of the population was the cultivation of coffee, cacao, and tropical fruits, such as oranges, bananas, and tangerines. In the past 20 years, the economy of the population has shifted primarily to the cultivation of coca leaves. Because the cocoa plant is easy to produce and there is a high demand for coca leaves, their cultivation has become the main occupation of the population. The high economic return of coca plants has attracted other nonblack populations to the area. Therefore, in Chicaloma there are black and nonblack populations dedicated to the cultivation and trade of coca leaves. In general, land ownership tends to be more in the hands of blacks than nonblacks because blacks were the first colonizers of the area. Hence, the socioeconomic status of the blacks is higher than that of the nonblacks. 


\section{Origin of black population in Chicaloma and Bolivia}

According to historical accounts, the black population of Bolivia came from the Spanish slave trade practiced prior to independence. Most of the black slaves during Spanish colonization were brought from West Africa to the ports of Buenos Aires, Argentina, and Lima, Peru (Crespo, 1977; Portugal, 1978; Criales, 1992). From there, the black slaves were taken to work as laborers in the land holdings of the Spaniards. Others were sold to work in the silver mines of Bolivia and Peru. It is estimated that $\sim 1,000$ slaves were transported to work in the silver mines of Potosi, located at an altitude above 4,500 $\mathrm{m}(15,114 \mathrm{ft})$ in the northeastern region of Bolivia. As a consequence of the harsh working conditions and extreme altitude, a large percentage of the black population died. Some of the surviving slaves escaped to the tropical lowlands, whereas others were sold to landowners in the lowlands (Criales, 1992). Since then, the black population has inhabited various areas of the tropical and subtropical regions of northeastern Bolivia. At present, there are $~ 6,000$ members of this population living in the eastern tropical region of Bolivia known as the Yungas.

In 1953, the agrarian reform of Bolivia began and granted ownership of the land to the slaves. As a consequence, black slaves and other non-black settlers became small landowners. Other recent migrants or recent colonizers, such as mestizos, Aymaras, and Quechuas, have become tenants of both black and nonblack earlier settlers. Prior to the demand for coca leaves, the subsistence economy of the populations in the subtropical regions, referred to as the Yungas, was based on the agriculture of traditional products, such as coffee, cacao, sugar, and fruits. However, when the drug trade of cocaine increased, the demand for coca leaves also increased, causing a shift to coca cultivation almost entirely. Therefore, in recent times, the major cash crop of the Yungas and of the Chicaloma population has been the cultivation of coca leaves.

\section{Measurements and analysis}

The study includes measurements of socioeconomic status, anthropometric estimates of body composition, blood pressures, genetic markers, serum lipids, and dietary practices. It should be noted that due to logistic difficulties the sample sizes were not the same for every measurement. Hence, the number of subjects are given for every variable included in the analysis.

\section{Socioeconomic status}

Language and level of education. Information on level of education and language spoken were obtained from questionnaires administered to the heads of the households. The questionnaires gathered information about: (1) level of education (questions ranging from literacy level to level of completed Bolivian education) and (2) language knowledge (whether the individual spoke Quechua, Aymara, or Spanish). The level of education was similar in both ethnic groups (Woodill, 1996). Although there are no differences between blacks and nonblacks in the number of people who speak Spanish, a significantly greater number of nonblacks speak Aymara.

Economic status. Information about economic traits were obtained from questionnaires administered to the heads of households. The questionnaires gathered information about: (1) house ownership, number of rooms in the house (other than the kitchen), (2) type of roof and floor, (3) type of walls in the house, (4) bathroom facilities (outside, latrine, washroom), (5) access to electricity, and (6) household items such as radio, tape recorder radio, sewing machine, bicycle, blender, refrigerator, car or motorcycle, upholstered furniture, and television set.

\section{Anthropometric dimensions}

The anthropometric data include height, weight, sitting height, and skinfold thicknesses measured at triceps, subscapular, midaxillary, suprailiac, thigh, and calf (Lohman et al., 1988; Frisancho, 1990). The body mass index (BMI), midupper arm muscle area, arm area, arm fat index, and sitting height index were calculated (Frisancho, 1990).

Measurements of whole body resistance were obtained with a bioelectrical impedance analyzer (Valhalla Scientific, San Diego, CA). Subjects assumed a supine position with arms and feet spread apart and shoes and socks removed. The detecting electrodes were placed on the dorsal aspect of the right wrist midway between the ra- 
TABLE 1. Socioeconomic characteristics of Chicaloma sample and subsamples of blacks and nonblacks

\begin{tabular}{lrrr}
\hline Item & \multicolumn{1}{c}{ Chicaloma } & \multicolumn{1}{c}{ Black } & Nonblack \\
\hline Years of education $^{1}$ & $5.17(\mathrm{n}=143)$ & $5.18(\mathrm{n}=80)$ & $5.17(\mathrm{n}=63)$ \\
Able to read $(\%)^{1}$ & $81.8(\mathrm{n}=143)$ & $85.0(\mathrm{n}=80) \dagger$ & $77.8(\mathrm{n}=63)$ \\
Speaks Aymara $(\%)^{1}$ & $25.9(\mathrm{n}=143)$ & $10.0(\mathrm{n}=80) \dagger$ & $46.0(\mathrm{n}=63)$ \\
Speaks Quechua $(\%)^{1}$ & $8.2(\mathrm{n}=143)$ & $2.8(\mathrm{n}=80) \dagger$ & $15.0(\mathrm{n}=63)$ \\
Speaks Spanish $(\%)^{1}$ & $98.0(\mathrm{n}=143)$ & $100.0(\mathrm{n}=80)$ & $95.2(\mathrm{n}=63)$ \\
Owns house $(\%)^{2}$ & $84.1(\mathrm{n}=157)$ & $87.8(\mathrm{n}=90) \dagger$ & $79.1(\mathrm{n}=67)$ \\
Has access to electricity $(\%)^{2}$ & $83.4(\mathrm{n}=157)$ & $88.9(\mathrm{n}=90) \dagger$ & $76.1(\mathrm{n}=67)$ \\
Owns refrigerator $(\%)^{2}$ & $25.5(\mathrm{n}=157)$ & $28.9(\mathrm{n}=90) \dagger$ & $20.9(\mathrm{n}=67)$ \\
Owns television set $(\%)^{2}$ & $54.8(\mathrm{n}=157)$ & $63.3(\mathrm{n}=90) \dagger$ & $43.3(\mathrm{n}=67)$ \\
\hline${ }^{1}$ Adapted from Woodill $(1996)$ based on partial sampler. & & \\
${ }^{2}$ Based on a more complete sample. & & & \\
& & & \\
& & &
\end{tabular}

dial and lunar processes and the anterior aspect of the right ankle midway between the tibia and fibia's malleoli.

Lean body mass was calculated using the equation of Kushner et al. (1992) for estimating total body water which was modified to provide a new population-specific equation for estimating lean body mass:

Lean body mass $(\mathrm{kg})=$

$$
2.395+(0.864 \times(\mathrm{H} 2 / \mathrm{R})-(0.009 \times \mathrm{E}),
$$

where $\mathrm{H}=$ Height, squared, $\mathrm{R}=$ resistance from bioelectric impedance, $\mathrm{E}=$ ethnicity: $1=$ black, $2=$ nonblack.

Measurements of skin reflectance were made with a Photovolt Reflectometer, Model 575. Reflectance readings were made following the same procedures used in a previous study (Frisancho et al., 1981). This included measurements with two filters identified as triamber and trigreen. These filters have transmission peaks of $\sim 600 \mathrm{~nm}$ (triamber), and $550 \mathrm{~nm}$ (trigreen) (Conway and Baker, 1972; Frisancho et al., 1981). At least two readings on the inner arm distal to the axillary region were obtained on each participant. The readings on the inner arm with the triamber and green filters were averaged.

Because of nonnormal distributions, the sum of skinfolds and mean skin reflectance were $\log 10$ transformed.

\section{Blood pressures}

Blood pressures were measured in a sitting position. Systolic and diastolic blood pressures were obtained on three occasions: during the initial anthropometric evaluation, during specific health evaluation, and at the end of the examination. The results of the three readings were averaged. Each reading was done using both a manual sphygmomanometer and a battery operated blood pressure monitor and was taken after the subject rested quietly for at least $5 \mathrm{~min}$. The advantage of using automated equipment eliminated the observer bias and/or reading preference and minimized training time.

\section{Serum lipids}

At the examinations in Chicaloma blood was drawn into tubes with $0.1 \mathrm{~g}$ EDTA as anticoagulant after a $12-14 \mathrm{~h}$ overnight fast. Blood tubes were immediately placed on ice, and plasma was separated by centrifugation at $1,000 \times \mathrm{g}$ for $20 \mathrm{~min}$ at $4^{\circ} \mathrm{C}$ within $4 \mathrm{~h}$. The analysis of cholesterol, high density lipoproteins (HDL), low density lipoproteins (LDL), and triglycerides were done at the Biochemistry Laboratory at the Instituto Boliviano de Altura (IBBA) following standard procedures (Friedewald et al., 1972):

\section{LDL cholesterol $(\mathrm{mmol} / \mathrm{L})=$ [total cholesterol $(\mathrm{mmol} / \mathrm{L})$ - HDL cholesterol $(\mathrm{mmol} / \mathrm{L})-$ triglyceride $(\mathrm{mmol} / \mathrm{L})] / 2.18$. \\ RESULTS \\ General characteristics}

As noted earlier, there are no differences between blacks and nonblacks in the number of people who speak Spanish, but a significantly greater number of nonblacks speak Aymara as described by Woodill (1996). About $84 \%$ of Chicaloma subjects own their house, $83 \%$ have access to electricity, $26 \%$ own refrigerators, and $55 \%$ own a television set (Table 1). Further, a significantly greater percentage of blacks own their house $(87.8 \%$ for blacks and $79.1 \%$ for nonblacks). Moreover, a significantly 
TABLE 2. Comparison of ownership index (OI) of blacks and nonblacks samples in Chicaloma

\begin{tabular}{lccccc}
\hline & \multicolumn{3}{c}{ Nonblack } \\
Item & $\mathrm{N}$ & Mean $\pm \mathrm{SE}$ & $\mathrm{N}$ & Mean $\pm \mathrm{SE}$ & $P$ \\
\hline House ownership & 90 & $0.91 \pm 0.05$ & 67 & $0.71 \pm 0.08$ & $<0.05$ \\
Electricity & 90 & $1.10 \pm 0.04$ & 67 & $0.90 \pm 0.06$ & $<0.05$ \\
Refrigerator & 90 & $1.10 \pm 0.20$ & 67 & $0.80 \pm 0.20$ & $<0.01$ \\
Television & 90 & $1.20 \pm 0.09$ & 67 & $0.80 \pm 0.11$ & $<0.01$ \\
Ownership index (OI) & 90 & $4.30 \pm 0.3$ & 67 & $3.30 \pm 0.31$ & $<0.01$ \\
\hline
\end{tabular}

greater percentage of blacks have access to electricity $(88.9 \%$ for blacks and $76.1 \%$ for nonblacks), own a refrigerator $(28.9 \%$ of blacks and $20.9 \%$ of nonblacks) own a television set $(63.3 \%$ of blacks and $43.3 \%$ for nonblacks). Overall, blacks have a higher economic status than nonblack samples.

To investigate the relationship between socioeconomic status and blood pressures, an ownership index (OI) was calculated. The index is based on population reciprocals for the frequencies of (1) home ownership, (2) access to electricity, (3) possession of a television set, and (4) possession of a re- frigerator. For example, the OI for house ownership in the population as a whole would equal $1.19(1 / 84.1 \times 100=1.19), 1.20$ for access to electricity $(1 / 83.4 \times 100=1.20)$, 3.92 for ownership of refrigerator (1/ $25.5 \times 100=3.92$ ), and 1.82 for ownership of a television set $(1 / 54.8 \times 100=1.82)$. In this manner, each household was accorded an OI depending on whether or not it owned its home, had access to electricity, owned a television set, and a refrigerator. The use of reciprocals gave the greatest weighting to the least frequently owned of these four amenities.

TABLE 3. Anthropometric characteristics and skin reflectance of blacks and nonblacks in Chicaloma

\begin{tabular}{|c|c|c|c|c|c|}
\hline Variable & $\mathrm{N}$ & $\begin{array}{c}\text { Black } \\
\text { Mean } \pm \text { SE }\end{array}$ & $\mathrm{N}$ & $\begin{array}{l}\text { Nonblack } \\
\text { Mean } \pm \text { SE }\end{array}$ & F-test \\
\hline \multicolumn{6}{|l|}{ Males } \\
\hline Age $(y r)$ & 37 & $39.2 \pm 2.1$ & 25 & $39.3 \pm 2.6$ & n.s. \\
\hline Height $(\mathrm{cm})$ & 37 & $165.8 \pm 1.2$ & 25 & $159.4 \pm 1.6$ & $P<0.01$ \\
\hline Weight (kg) & 37 & $63.1 \pm 0.9$ & 25 & $59.3 \pm 1.8$ & $P<0.01$ \\
\hline BMI (kg/m2) & 37 & $22.9 \pm 0.3$ & 25 & $23.2 \pm 0.4$ & n.s. \\
\hline St. height $(\mathrm{cm})$ & 37 & $83.6 \pm 0.6$ & 24 & $84.8 \pm 0.8$ & n.s. \\
\hline St. height index $(\%)$ & 37 & $50.5 \pm 0.4$ & 24 & $53.0 \pm 0.3$ & $P<0.01$ \\
\hline Sum skin folds (mm) & 37 & $33.9 \pm 1.7$ & 25 & $42.1 \pm 3.4$ & $P<0.01$ \\
\hline Midupper arm muscle (cm2) & 37 & $50.5 \pm 1.2$ & 25 & $46.4 \pm 1.1$ & $P<0.05$ \\
\hline Arm fat index $(\%)$ & 37 & $16.7 \pm 1.1$ & 25 & $18.0 \pm 1.2$ & n.s. \\
\hline Bioimpedance $(\Omega)$ & 37 & $451.4 \pm 6.4$ & 24 & $469.4 \pm 10.9$ & n.s. \\
\hline Height $2 / \mathrm{R}(\Omega)$ & 37 & $61.5 \pm 1.2$ & 24 & $55.5 \pm 1.8$ & $P<0.01$ \\
\hline Lean body mass $(\mathrm{kg})^{1}$ & 37 & $55.5 \pm 1.1$ & 24 & $50.3 \pm 1.6$ & $P<0.01$ \\
\hline Body fat $(\mathrm{kg})^{1}$ & 37 & $7.6 \pm 0.7$ & 24 & $9.7 \pm 1.0$ & n.s. \\
\hline Body fat $(\%)^{1}$ & 37 & $12.1 \pm 1.1$ & 24 & $16.0 \pm 1.6$ & $P<0.015$ \\
\hline Mean skin reflectance (\%) & 36 & $14.6 \pm 0.8$ & 25 & $21.5 \pm 0.6$ & $P<0.01$ \\
\hline \multicolumn{6}{|l|}{ Females } \\
\hline Age $(\mathrm{yr})$ & 55 & $39.0 \pm 1.9$ & 42 & $36.8 \pm 2.3$ & n.s. \\
\hline Height $(\mathrm{cm})$ & 55 & $154.1 \pm 0.9$ & 42 & $148.6 \pm 0.8$ & $P<0.01$ \\
\hline Weight (kg) & 55 & $56.7 \pm 1.2$ & 42 & $52.9 \pm 1.1$ & $P<0.01$ \\
\hline BMI (kg/m2) & 55 & $24.0 \pm 0.5$ & 42 & $24.0 \pm 0.5$ & n.s. \\
\hline St. height $(\mathrm{cm})$ & 52 & $78.1 \pm 0.4$ & 40 & $77.7 \pm 0.5$ & n.s. \\
\hline St. height index (\%) & 52 & $50.7 \pm 0.3$ & 40 & $52.2 \pm 0.3$ & $P<0.01$ \\
\hline Sum skin folds (mm) & 54 & $62.2 \pm 3.7$ & 41 & $68.3 \pm 4.5$ & n.s. \\
\hline Midupper arm muscle (cm2) & 54 & $36.8 \pm 0.9$ & 41 & $34.5 \pm 1.2$ & n.s. \\
\hline Arm fat index $(\%)$ & 54 & $33.0 \pm 1.4$ & 41 & $36.9 \pm 1.5$ & n.s. \\
\hline Bioimpedance $(\Omega)$ & 47 & $502.9 \pm 7.1$ & 36 & $528.0 \pm 7.1$ & $P<0.01$ \\
\hline Height $2 / \mathrm{R}(\Omega)$ & 47 & $61.5 \pm 1.2$ & 36 & $55.5 \pm 1.8$ & $P<0.01$ \\
\hline Lean body mass (kg) & 47 & $43.5 \pm 0.7$ & 36 & $39.0 \pm 0.9$ & $P<0.01$ \\
\hline Body fat $(\mathrm{kg})$ & 47 & $12.2 \pm 0.9$ & 36 & $13.0 \pm 0.9$ & n.s. \\
\hline Body fat $(\%)$ & 47 & $21.3 \pm 1.2$ & 36 & $24.6 \pm 1.3$ & $P<0.01$ \\
\hline Mean skin reflectance $(\%)$ & 51 & $17.1 \pm 0.6$ & 38 & $23.6 \pm 0.6$ & $P<0.01$ \\
\hline
\end{tabular}

n.s. $=$ not significant. 
TABLE 4. Blood pressures and serum lipids of blacks and nonblacks in Chicaloma.

\begin{tabular}{|c|c|c|c|c|c|}
\hline Variable & $\mathrm{N}$ & $\begin{array}{c}\text { Black } \\
\text { Mean } \pm \mathrm{SE}\end{array}$ & $\mathrm{N}$ & $\begin{array}{l}\text { Nonblack } \\
\text { Mean } \pm \text { SE }\end{array}$ & F-test \\
\hline \multicolumn{6}{|l|}{ Males } \\
\hline Systolic blood pressure & 35 & $123.7 \pm 3.1$ & 25 & $107.4 \pm 2.2$ & $P<0.01$ \\
\hline Diastolic blood pre & 35 & $73.9 \pm$ & & & $P<0.01$ \\
\hline Cholesterol (mg) & 32 & $168.9 \pm 11.3$ & & $176.2 \pm 13.2$ & n.s. \\
\hline ty lipoprotein (mg) & 32 & $40.0 \pm 1.7$ & & $43.0 \pm 34.9$ & n.s. \\
\hline oprotein $(\mathrm{mg})^{1}$ & 32 & $104.2 \pm 6.5$ & 17 & 135.3 & n.s. \\
\hline & 32 & & & 103.05 & n.s. \\
\hline $\mathrm{mg} / 100 \mathrm{ml})$ & 27 & $14.6 \pm 0.3$ & 15 & $14.9 \pm$ & n.s. \\
\hline Hematocr & 27 & $43.3 \pm 0.6$ & 15 & $42.3 \pm 1.0$ & n.s. \\
\hline \multicolumn{6}{|l|}{ Females } \\
\hline Systolic blood pressure $(\mathrm{mmHg})$ & 54 & $119.2 \pm 2.8$ & 42 & $102.7 \pm 2.2$ & $P<0.01$ \\
\hline & 54 & & & & $P<0.01$ \\
\hline Choleste & 51 & $171.9 \pm 6.9$ & 36 & $173.9 \pm 8.7$ & n.s. \\
\hline & 51 & $48.7 \pm 1.7$ & 36 & & n.s. \\
\hline otein $(\mathrm{mg})^{1}$ & 51 & $111.7 \pm 6$ & 36 & $117.2 \pm$ & n.s. \\
\hline Triglycerides & 51 & $71.9 \pm 4.6$ & 36 & $80.3 \pm 8.4$ & n.s. \\
\hline Hemo & 50 & $12.5 \pm 0.2$ & 36 & $12.3 \pm 0.3$ & n.s. \\
\hline Hematocrit (\%) & 50 & $38.2 \pm 0.5$ & 36 & $36.5 \pm 0.5$ & n.s. \\
\hline
\end{tabular}

${ }^{1}$ Low density lipoprotein $(\mathrm{mg})=$ total cholesterol - high density lipoprotein - (Triglycerides $\left.\times 0.16\right)$. n.s. = not significant.

Results of this analysis indicate that blacks have a higher OI index than nonblacks (Table 2).

In terms of body size and body composition, blacks are significantly taller and heavier and have a greater midupper arm muscle area and higher lean body mass than nonblacks (Table 3). The mean skin reflectance is significantly lower in blacks than in nonblacks.

\section{Blood pressures and cholesterol}

Black males have significantly higher systolic and diastolic blood pressures, but lower serum cholesterols than nonblacks (Table 4). Similarly, black females have higher systolic and diastolic blood pressures than nonblacks, but have similar values of cholesterol, serum lipids, hemoglobin, and hematocrit concentrations (Table 4). The prevalence of hypertension (Table 5) is higher for blacks (7.9\% for systolic and 5.9\% for diastolic pressures) than nonblacks (1.3\%). Among black males and females, systolic and diastolic blood pressures increase with age, whereas among nonblacks there are no age-associated increases (Figs. 1 and 2).

Multiple regresion analyses were conducted with blood pressures as the dependent variable and age, sex, weight, BMI, sum of skinfold thicknesses, lean body mass, fat weight, percent fat weight, OI, and skin reflectance as independent vari- ables. A series of regression analyses were run whereby the least important variables were excluded and only the important variables were included in the final equation. The results indicate that skin reflectance, age, and ethnicity are the most important predictors of variability in blood pressures (Table 6). However, OI, weight, BMI, sum of skinfolds, lean body mass, body fat $(\mathrm{kg})$, body fat $(\%)$ have the least influence on blood pressures. Figure 3 shows that skin reflectance in the Chicaloma sample is inversely related to blood pressures so that the darker the skin reflectance the higher the blood pressures. As inferred from the correlations $(r=-0.43$ to -0.49 for systolic blood pressure and $r=-0.30$ to -0.47 for diastolic blood pressure), $\sim 9-24 \%$ of the variability in blood pressure is related to variability in skin color. Serum cholesterol in Chicaloma is significantly influenced

TABLE 5. Frequency of hypertension among blacks and nonblacks in Chicaloma, with comparative data for U.S. blacks

\begin{tabular}{|c|c|c|c|}
\hline & $\begin{array}{c}\text { Chicaloma, } \\
\text { Bolivia } \\
\text { Nonblack }(\%)\end{array}$ & $\begin{array}{c}\text { Black } \\
(\%)\end{array}$ & $\begin{array}{l}\text { U.S. }^{1} \\
\text { Black }\end{array}$ \\
\hline \multicolumn{4}{|c|}{ Systolic blood pressure $>160 \mathrm{~mm} \mathrm{Hg}$} \\
\hline Males & 0.0 & 7.3 & 30.1 \\
\hline Females & 2.3 & 8.3 & 31.2 \\
\hline Total & 1.3 & 7.9 & 30.5 \\
\hline \multicolumn{4}{|c|}{ Diastolic blood pressure $>95 \mathrm{~mm} \mathrm{Hg}$} \\
\hline Males & 0.0 & 2.4 & 31.2 \\
\hline Females & 2.3 & 8.3 & 31.2 \\
\hline Total & 1.3 & 5.9 & 30.5 \\
\hline
\end{tabular}

${ }^{1}$ National Center for Health Statistics (1977). 

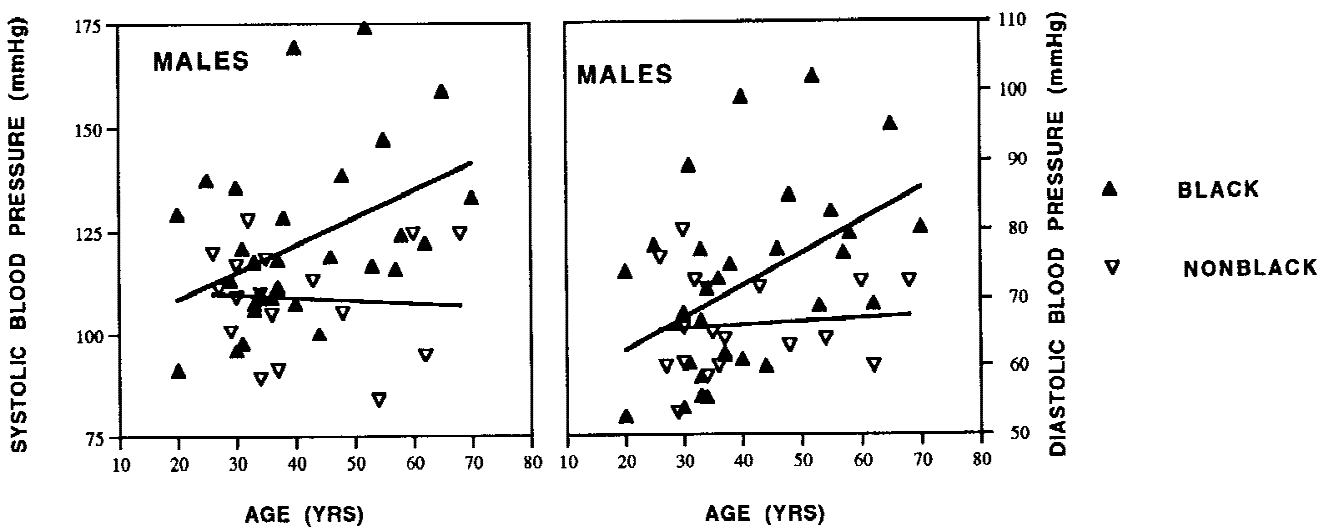

Fig. 1. Relationship of blood pressure and age among Chicaloma male samples. Note that among blacks, both systolic and diastolic blood pressures increase with age, whereas among nonblacks, they remain constant throughout all ages.

only by body fat. Similarly, the ratio of low density lipids to cholesterol is significantly related to material ownership and ethnicity. The remaining variables have a nonsignificant influence on variability of serum lipids.

\section{DISCUSSION}

The frequency of hypertension among Chicaloma blacks is much lower than that observed among U.S. blacks. These findings are similar to those reported in previous studies, in which the prevalence of hypertension in African-Americans is higher than that in Caribbean and Brazilian black populations (Johnson and Remington, 1961; Johnson et al., 1975; Rubeiro et al., 1981; Coroni-Huntsley et al., 1989; James et al.,
1991; Saunders, 1991). Various studies have hypothesized that high blood pressure among U.S. blacks is related to sociocultural stress related to the establishment and maintenance of a middle-class life style in dark compared to light skin individuals (Dressler, 1990, 1991; Moorman et al., 1991; Calhoun, 1992; Williams, 1992). According to this hypothesis, the important issue is the status ascribed to the darker phenotype irrespective of the achievement of any given status level, i.e., the stresses associated with darker skin color have to do with the contribution that skin color per se makes to status attainment. In the population of Chicaloma, "blackness" is not associated with any negative status. In fact, the opposite oc-
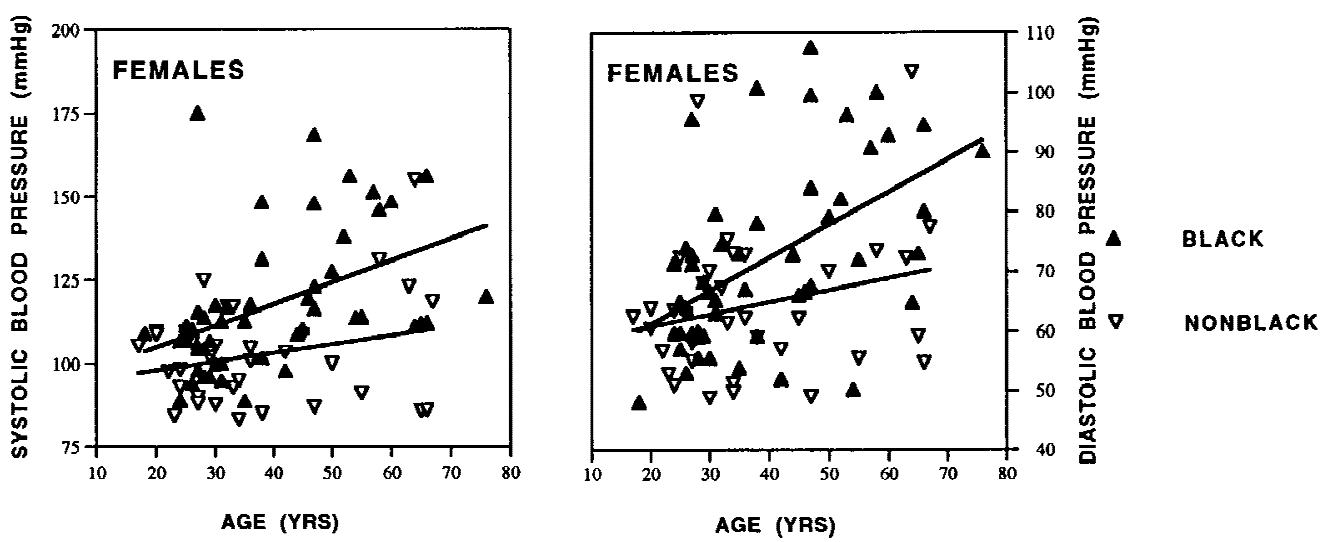

Fig. 2. Relationship of blood pressure and age among Chicaloma female samples. Note that among blacks, both systolic and diastolic blood pressures increase with age, whereas among nonblacks, they remain constant throughout all ages. 
TABLE 6. Results of multivariate regression analyses of the best predictors of blood pressures and serum lipids for the sample of Chicaloma

Variable $\mathrm{R}$

Systolic blood pressure

$\mathrm{Y}=166.64-(45.67 \times$ skin reflectance $)+(0.38 \times$ age $)-(9.30 \times$ ethnicity $)$ (best predictor $)$

Not included in equation (poor predictors)

OI, weight, BMI, sum of skinfolds, lean body mass, body fat $(\mathrm{kg})$, body fat (\%)

Diastolic blood pressure

$\mathrm{Y}=91.10-(27.94 \times$ skin reflectance $)+(0.38 \times$ age $)$ (best predictor $)$

Not included in equation (poor predictors)

OI, weight, BMI, sum of skinfolds, lean body mass, body fat (kg), body fat (\%), ethnicity

Serum cholesterol

$\mathrm{Y}=144.72-(248 \times$ body fat, $\mathrm{kg})$ (best predictor)

Not included in equation (poor predictors)

Age, weight, BMI, sum of skinfolds, lean body mass, body fat (\%), OI, skin reflectance, ethnicity

Ratio of low density lipid to cholesterol

$\mathrm{Y}=54.08+(1.16 \times \mathrm{OI})+(4.18 \times$ ethnicity) (best predictor)

Not included in equation (poor predictors)

Age, weight, BMI, sum of skinfolds, lean body mass, body fat (\%), skin reflectance

curs in that the principal local authorities are black. Because they are the major producers of the cash crop of the village, blacks have a higher or equal socioeconomic status as nonblacks. As indicated by material OI, blacks enjoy better economic conditions than nonblacks. Analyses of growth status and dietary intakes indicate that black children also have a higher standard of living than nonblacks (Woodill, 1996). These findings together suggest that the tendency toward high blood pressures among blacks from Chicaloma cannot be explained solely due to the influence of socio-cultural factors. However, it is possible that the tendency toward high blood pressures of blacks reflects the effects of transition from lower to higher socioeconomic status. In developing societies, a direct association between socioeconomic status and blood pressures emerges first. At later stages of economic development, the association changes to the inverse pattern observed in industrialized nations. If this is the case, the increased tendency toward higher blood pressures of blacks would be related to the transition from a rural to urban environment.

It is also possible that blacks are predisposed to increased blood pressures due to the influence of genetic factors. Genetic studies among blacks from the islands of Barbados and La Desirade indicate that individuals having the largest proportion of African mitochondrial DNA have a higher mean systolic blood pressure and higher hypertension prevalence than those of nonAfrican lineage (Darlu et al., 1990). Studies on the alpha 2-adrenergic receptor gene polymorphism among hypertensive and normotensive U.S. black and white subjects in-
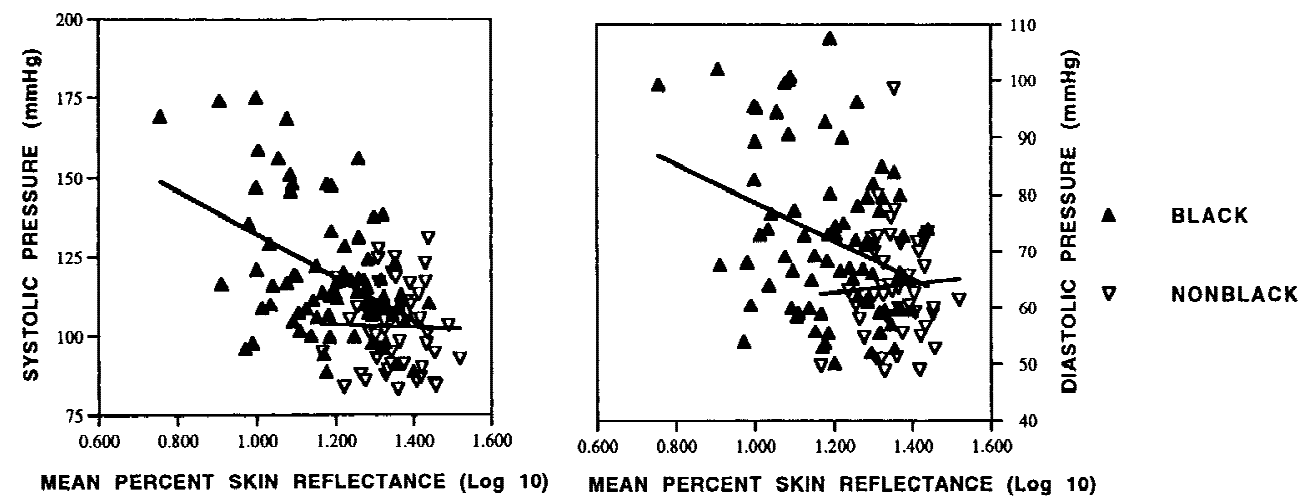

Fig. 3. Relationship of skin reflectance and blood pressures among Chicaloma samples. Note that among blacks, both systolic and diastolic blood pressures are significantly and inversely related to skin reflectance, whereas among nonblacks, there is no relationship between skin color and blood pressure. 
dicate that hypertensive blacks have a higher proportion of the abnormal short allele of alpha 2-adrenergic receptor gene than their normotensive counterparts (Freeman et al., 1995). In this study, 15.9\% (13 out of 82) of the black hypertensives were homozygous for the short abnormal allele of alpha 2-adrenergic receptor gene polymorphism, but only $3 \%$ ( 2 out of 59 ) normotensive blacks and none of the ( 0 out of 25) white hypertensive subjects, were homozygous for the shorter allele. Comparative studies indicate that $80-90 \%$ of black Nigerians had a mutant allele, which is thought to influence the renin-angiotensin system, but $47 \%$ of hypertensive whites in Paris and Salt Lake City, Utah, also had a mutant allele (Cooper, 1997). These studies together suggest that there are genetic differences associated with the increased frequency of hypertension in blacks.

Several studies indicate that variability in skin color reflectance is the result of the additive effects of 3-5 loci (Byard, 1981) and that $\sim 50-70 \%$ of the variability in skin reflectance is due to a heritable additive genetic component (Post and Rao, 1977; Frisancho et al., 1981). In the present study, skin reflectance per se accounts for $\sim 9-24 \%$ $(\mathrm{r}=-0.46$ for systolic pressure and $\mathrm{r}=$ -0.32 for diastolic pressure) of the variability in blood pressures. Similarly, multivariate regression analyses indicate that skin reflectance and age are the most important predictors of variability in blood pressures, whereas the material OI had the least effect on blood pressures and serum lipids. Thus, contrary to what has been suggested, the darker the skin color the higher the blood pressure, even at comparable levels of affluence.

In summary, the data suggest that genetic factors, as inferred from the association between blood pressures and skin reflectance, play a role, albeit small, in the risk to increased blood pressures. These findings suggest that genetic factors may predispose black individuals to increased blood pressures, but that the expression of clinical hypertension is under the influence of adverse unaccounted environmental factors.

\section{ACKNOWLEDGMENTS}

We thank Sanitarian Mr. Daniel Barra, for his enthusiastic assistance, the members of the city council, schoolteachers, and all the families of Chicaloma, Bolivia, that participated in the study. We are also grateful to Stanley M. Garn for his suggestions and comments, and to Patricia Juliao for her assistance in revising this manuscript. This study was supported in part by NIHFogarty Minority International Research Training grant lT3700035 to the Center for Human Growth.

\section{LITERATURE CITED}

Aviv A, Aladjem M. 1990. Essential hypertension in blacks: Epidemiology, characteristics, and possible roles of racial differences in sodium, potassium, and calcium regulation. Cardiovasc Drugs Therapy 4(Suppl 2):335-342.

Byard PJ. 1981. Quantitative genetics of human skin color. Yrbk Phys Anthropol 24:123-137.

Calhoun DA. 1992. Hypertension in blacks: Socioeconomic stress and sympathetic nervous system activity Am J Med Sci 304:306-311.

Conway DL, Baker PT. 1972. Skin reflectance of Quechua Indians: The effects of genetic admixture, sex, and age. Am J Phys Anthropol 36:267-282.

Cooper R, Rotimi C, Ataman S, McGee D, Osotimehin B, Kadiri S, Muna W, Kingue S, Fraser H, Forrester T, Bennett F, Rainford W. 1997. The prevalence of hypertension in the seven populations of West African origin. Am J Publ Health 87:161-168.

Coroni-Huntley J, LaCroix AZ, Havlik RJ. 1989. Race and sex differentials in the impact of hypertension in the United States. Arch Intern Med 149:780-788.

Crespo A. 1977. Los esclavos negros en Bolivia. La Paz: Academia Nacional de Ciencias. Imprenta Unidad.

Criales H. 1992. La raza negra en la altura. La Paz, Bolivia In: Lazo de la Vega B and Eranda E, editors. Biblioteca de Medicina. Tomo IV. Facultad de Medicina, Enfermeria, Nutricion y Tecnologia Medica.

Darlu P, Sagnier PP, Bois E. 1990. Geneological and genetical African admixture estimations, blood pressure and hypertension in a Caribbean community. Ann Hum Biol 17:387-397.

Dressler WW. 1990. Lifestyles, stress, and blood pressure in a southern black community. Psychosom Med 52:182-198.

Dressler WW. 1991. Social class, skin color, and arterial blood pressure in two societies. Ethnic Dis 1:60-77.

Dressler WW, Dos Santos JE, Gallagher Jr, PN, Viteri FE. 1987. Arterial blood pressure and modernization in Brazil. Am Anthropol 89:398-408.

Freeman K, Miranda T, Weder A, Farrow S, Lockette W. 1995. A genetic polymorphism of the alpha-2 adrenergic receptor is associated with increased exercise-induced sweat sodium excretion in humans. (unpublished manuscript)

Freeman K, Farrow S, Schmaier A, Freedman R, Schork T, Lockette W. 1995. Genetic polymorphism of the alpha 2-adrenergic receptor is associated with increased platelet aggregation, baroreceptor sensitivity, and salt excretion in normotensive humans. Am J Hyperten 9:863-869.

Friedwald WT, Levy RE, Frederickson DS. 1972. Estimation on the concentration of low density lipoprotein cholesterol in plasma without use of the ultracentrifuge. Clin Chem 18:499-502. 
Frisancho AR. 1990. Anthropometric Standards for the Assessment of Growth and Nutritional Status. Ann Arbor: University of Michigan Press.

Frisancho AR, Leonard WR, Bollettino LA. 1984. Blood pressure in blacks and whites and its relationship to dietary sodium and potassium intake. J Chron Dis 34:515-519.

Frisancho AR, Wainwright, Way A. 1981. Heritability and components of phenotypic expression in skin reflectance of Mestizos from the Peruvian Lowlands. Am J Phys Anthropol 55:203-208.

Gleibermann L. 1973. Blood pressure and dietary salt in human populations. Ecol Food Nutri 2:143-156.

Gleibermann LK. 1975. Aspects of sodium metabolism: Implications for population variation in blood pressure. Doctoral dissertation, University of Michigan, Ann Arbor.

Grim CE, Luft FC, Miller JZ, Meneely GR, Batarbee HD, Hames CG, Dahl LK. 1980. Racial differences in blood pressure in Evans County, Georgia: Relationship to sodium and potassium intake and plasma renin activity. J Chron Dis 33:87-94.

Hall WD. 1990. Pathophysiology of hypertension in blacks. Am J Hyperten 3:366S-371S.

James SA, de Almeida-Filho N, Kaufman JS. 1991. Hypertension in Brazil: A review of the epidemiological evidence. Ethnic Dis 1:91-98.

Johnson AL, Cornoni JC, Cassel JC, Tyroler HA, Heyden S, Hames CG. 1975. Influence of race, sex and weight on blood pressure behavior in young adults. Am J Cardiol 35:523-530.

Johnson B, Remington RD. 1961. A sampling study of blood pressure levels in white and Negro residents of Nassau, Bahamas. J Chron Dis 3:39-51.
Kushner RF, Schoeller DA, Fjeld CR, Danford L. 1992. Is the impedance index (ht2/R) significant in predicting total body water? Am J Clin Nutr 56:835-839.

Lohman TG, Roch AF, Martorell R, editors. 1988. Anthropometric Standardization Reference Manual. Champaign, IL: Human Kinetics.

Luft FC, Grim CE, Higgins JT, Weinberger MH. 1977. Differences in response to sodium administration in normotensive black and white subjects. J Lab Clin Med 90:555-562.

Moorman PG, Hames CG, Tyroler HA. 1991. Socioeconomic status and morbidity and mortality in hypertensive blacks. Cardiovas Clin 21:179-194.

National Center for Health Statistics. 1977. Blood pressure levels of persons 6-74 years, United States, 1971-1974. Vital and Health Statistics. Series 11, No. 203.

Portugal Ortiz M. 1978. La esclavitud negra en la epoca colonial y nacional de Bolivia. La Paz: Instituto Bolivian de Cultura.

Post PW, Rao DC. 1977. Genetic and environmental determinants of skin color. Am J Phys Anthropol 47: 399-402.

Ribeiro MBD, Ribeiro ABN, Neto CS. 1981. Hypertension and economic activities in São Paulo, Brazil. Hypertension 3 (suppl 2):233-237.

Saunders E. 1991. Hypertension in blacks. Primary Care; Clinics in Office Practice. 18:607-622.

Williams DR. 1992. Black-white differences in blood pressure: The role of social factors. Ethnic Dis 2:126141.

Woodill LM. 1996 Growth variation in a rural community of lowland Bolivia. Unpublished Master's thesis, University of Guelph, Canada. 